\title{
MELAMPAUI POLITISI, MENUJU NEGARAWAN: REFLEKSI ETIS KRISTIANI
}

\author{
Togardo Siburian \\ Sekolah Tinggi Teologi Bandung
}

\begin{abstract}
This article wants to study the possibility of principles of stateman for politician in these days. As we know, most politicians behave and conduct more as a handiman of politics, instead of a stateman (used to be called "politicos"). Therefore Christian reflection on ethics became essential to comprehend the imbalance practice and concept that emerged. This studies is done from ethical perspective through library research. Out of the three things mentioned that make political issues today chaotic particularly is: 1) A detached politics from ethics, 2) political study today only focused on law and social studies, 3) and forget philosophical and historical perspective to the study. Based on the way of ethical politics today, we found a principles that enrich ecclesiastical mandate and transformation in society.
\end{abstract}

KEYWORDS: political matters, ethics, politician, stateman, Christian, transformation, mandate, church.

ABSTRAK: Artikel ini ingin mengkaji kemungkinan negarawan bagi para politisi sekarang. Seperti diketahui kebanyakan sikap dan perilaku pemain politik (politician) menggambarkan mereka sebagai "tukang" politik saja, bukan seorang negarawan (dulu disebut "politikos"). Di sini refleksi kristiani menjadi urgen dalam memikirkan ketimpangan-ketimpangan praktik dan konsep yang muncul. Kajian yang dilakukan bersifat etis kristiani melalui studi pustaka. Dari tiga hal yang membuat perpolitikan masa kini karut marut adalah: 1) terlepasnya perpolitikan sekarang dari etika sebagai wadahnya, 2) terlalu menekankan fokus hukum dan perspektif sosial saja, 3) serta melupakan perspektif filosofis dan sejarah dalam kajiannya. Maksudnya dalam rangka mentransformasi konsep politisi untuk menjadi konsep negarawan yang membangun bangsa dan mensejahterakan 
rakyatnya, khususnya dalam soal kemiskinan. Berdasarkan jalan politik etis, maka didapatkan prinsip-prinsip yang dapat memperkaya bahan bagi mandat gerejawi masa kini dalam hal mandat transformasinya di masyarakat.

KATA-KATA KUNCI: perpolitikan, etika, politisi, negarawan, kristiani, transformasi, mandat, gereja.

\section{Pendahuluan}

Pemilu atau pilkada berakhir, demikian juga kepala negara dan kepala daerah yang terpilih secara sah sudah dilantik dan bekerja. Namun usaha para politisi masih belum berakhir untuk mendapatkan kekuasaan dan mengambil kursi jabatan tertentu lagi. Seharusnya para politisi yang telah memangku jabatan negara dapat mentransformasi diri menjadi negarawan. Negarawan adalah seseorang pejabat negara yang mengayomi semua golongan, termasuk golongan yang kalah dalam pemilu. Faktanya, banyak politisi yang sempit dalam pandangan kebangsaaan dan kenegaraan, serta masih berpihak pada golongannya dan mementingkan partainya saja. Ini sesuatu yang sangat tidak bermanfaat bagi rakyat, masyarakat, dan negara, karena para pejabat hanya memikirkan kepentingan diri dan kelompoknya.

Akhir-akhir ini banyak peristiwa yang memberikan contoh bahwa sikap negarawan sudah tidak ada lagi dalam diri para politisi dan pejabat negara, bahkan mantan pejabat dan pemimpin. Mereka kembali bersikap dan bertindak penuh taktik, layaknya dulu ketika menjadi politisi dan partisan partai. Hal ini telah membuat kegaduhan dalam masyarakat, sehingga urusan rakyat terabaikan, karena banyak waktu dihabiskan untuk berkonflik dalam interes politik sesaat. Semua demi kursi dan mempertahankan kuasa semata. Diskusi ini menjadi penting untuk pencerahan, bukan saja bagi pemain politik, tetapi juga pengamat politik untuk berefleksi secara intelektual atas situasi ini. Bahkan dapat dipakai 
sebagai peringatan bagi pembelajar politik demi masa depan bangsa dan peradaban manusia.

Khusus kajian etika kristiani, sedikitnya ada beberapa keprihatinan untuk bahan evaluasi tulisan ini: 1) Mengapa perpolitikan sekarang kehilangan nilai-nilai moral kemasyarakatan dan pondasi kemanusiaan? 2) Pentingnya etika kristiani yang diperluas refleksinya sampai ke bidang kehidupan sosial-politik dalam rangka mandat transformatif gereja. 3) Menyarankan kembali konsep politikus-negarawan bagi para politisi agar dapat menanggulangi permasalahan kesejahteraan rakyat, khususnya soal kemiskinan rakyat.

\section{Hilangnya Nilai-nilai Moral-Etik dalam Politik Praktis}

Pada tahap kajian, kita harus melihat betapa pentingnya etika dalam perpolitikan, khususnya pada politik kekuasaan. Selama ini, rakyat dan bangsa yang diperjuangkan dan diwakili hanyalah alat menuju kursi kekuasaan. Fenomena itu adalah realitas sehari-hari bagi penikmat media dalam menyaksikan panggung-panggung politik. Konsekuensinya, rakyat tidak percaya omong-omong politik lagi, karena semua penuh dengan keinginan tersembunyi atau konspirasi. Sehingga aksioma "politik itu jahat" memang tidak terelakkan. Padahal secara deskritif, politik itu sendiri netral. Namun kelak kalau sudah dimainkan bahkan ketika didiskusikan kelihatan tidak netral, dalam arti memihak yang jelek bahkan jahat demi keuntungan diri sendiri. Di sini diasumsikan, tanpa karakteristik moral, maka dunia perpolitikan akan rapuh dalam kebajikan dan cenderung menjadi jahat dalam kebijakan, karena penuh dengan intrik pribadi demi jabatan dan kekuasaan.

Seharusnya politik adalah hal moral, karena dikaji dari pemikiran etis yang mendalam dan secara sistematis logis. Sedangkan kajian etika sosial, harus berani lebih komprehensif mencakup isu-isu dilematis dalam kehidupan berbangsa dan bernegara. Artinya, bukan hanya sampai pada "etika berpolitik" dalam arti tata-cara etis berprofesi sebagai politisi. Studinya bukan sekadar membicarakan kode etik profesi bagi para politisi 
dalam mengatur etiket berorganisasi dalam parpol dan kelembagaan negara. Kajiannya harus sampai pada dasar-dasar moral yang solid dan kebajikan universal manusia, demi kesejahteraan bangsa dan negara secara keseluruhan. Ini bukanlah pragmatisme belaka, namun yang diperlukan adalah landasan ideal di dalam panggilan politik terkait isu-isu kemanusiaan yang lebih luas, Di sini kajian etika politik terpanggil dalam idealisme pemikiran dan praktek dalam menjalani tujuan dan tugas berbangsa dan berkemanusiaan, demi keadilan dan kesejahteraan rakyat.

Sayangnya, tidak ada lagi prinsip kepemimpinan bangsa dari para politisi ini; yang tersisa hanya penguasaan politik dalam arti "kursi" dan “jabatan” yang diperebutkan, namun sangat kecil pengaruh kepemimpinan yang dirasakan langsung oleh rakyat dan warga negara. Itu semua ditandai dengan adanya "jarak" yang jauh antara rakyat dan petinggi yang berkuasa, lengkap dengan sebutan feodalisme "Yang terhormat". Sikap negarawan tidak muncul dari para politisi tersebut. Jiwa negarawan yang adalah pelayan warga negara tidak ada.

Semula diidealkan sikap dan sifat negarawan adalah sikap dari seorang "politikos", yaitu pemimpin sejati bagi warganya. Pada awalnya, politik adalah urusan publik sebuah kota yang di dalamnya ada warga kota sebagai penduduk. Perpolitikan pada level itu dibicarakan dalam wacana etika, tepatnya di bawah studi filsafat moral. Tujuannya untuk mengkaji halhal pengaturan hidup kemasyarakatan demi kedamaian dan kebahagiaan bersama dari seluruh penduduk kota. Plato misalnya, menunjukkan beberapa aspek politis yang paling sederhana, yaitu: organisasi sosial, masyarakat beradab di antara penduduknya, demi kemanfaatan pentingnya unsur pendidikan moral. Buku ini diterjemahkan menjadi "Republic" yang berakar kata "res" (dunia atau bumi) dan "publica" (umum atau bersama). Pengertian republik di sini tidak boleh dimaknai sebagai "partai politik sayap kanan" yang secara khusus menunjuk pada pandangan politik konservatif, seperti pada masa kini. Secara sederhana mungkin dapat diterapkan pada sistem politik demokrasi, sejak era modern. Aristoteles 
memunculkan konsep politeia yang maknanya secara teknis dan adalah "konstitusi"1 yang secara sederhana berpengertian kemasyarakatan atau kewarganegaraan. Walau pada waktu itu, eksistensi suatu negara lebih menunjuk pada "negara-kota" yang monolitik daripada suatu "negarabangsa" yang pluralistik seperti pada masa kini. Sekarang ini lebih menekankan sipilitas rakyat dalam sistem politik demokrasi yang lebih kompleks.

Selanjutnya, Aristoteles dalam Nichomachean Ethics mengkategorikan jenis kekuasaan dengan menekankan pentingnya hal-hal baik, yaitu kebajikan moral untuk manusia, yang diikuti oleh intelektual moral menuju kesenangan dan kebahagiaan manusia, sebagai "kebaikan tertinggi" (eudaimonia). Konsep kebahagiaan sebagai kebaikan hidup dalam Aritoteles masuk ke dalam topik politik, khususnya tentang pentingnya legislasi, yang tidak harus dimengerti sebagai sistem perundang-undangan yang kompleks, seperti di dalam "parlemen" masa kini. Di sini etika adalah sebagai bahasan "transisional" menuju wacana politik. Aristoteles memang menekankan pentingnya aspek-aspek hukum, peraturan, dan kebiasaan dalam perundang-undangan suatu negara kota untuk mencapai kebaikan masyarakat dalam persaudaraan warga kota. Secara keseluruhan dalam buku ini, politik adalah bagian kecil dari keseluruhan aliran kehidupan etis; untuk masa kini dapat diartikan bahwa etika kehidupan bermasyarakat dipakai sebagai pondasi perpolitikan. Walau Aristoteles sendiri menolak sistem demokrasi yang dicurigainya cenderung jatuh ke dalam anarkhi, dan memilih sistem pemerintahan aristokrasi, yang dipimpin oleh para filsuf. Namun di dalamnya sudah mengindikasikan apa yang dikenal masa kini sebagai "prinsip keteraturan hidup bernegara dan kesejahteraan hidup bersama." 2 Pandangan historis itu berarti tidak ada halangan dan

\footnotetext{
1 Desmon Lee, penerjemah "Republic", pertama sekali mendasari pengantarnya dengan subjudul ethics dan memulai dengan: The republics start with moral and political question: What is justice? Dan menunjuk kata "dikaiosunee is a wide one and covers both individual and community, both ethics and politics." Lih. Plato, Republic, terj. (New York: Penguin Books, 2003), xxxiii dst. 2 Untuk melihat karakter-karakter etis ini lebih mendalam dapat melihat buku bahasan Yosef Koten, Partisipasi Politik: Sebuah Analisis atas Etika Politik Aristoteles (Maumere: Ladalero, 2010),
} 
sandungan, namun merupakan dasar moral-etis berkemanusiaan yang harus disadari oleh setiap politisi masa kini. Aksioma sosial yang terkenal adalah manusia sebagai zoon politikoon, "makhluk bermasyarakat" tentu mengindikasikan adanya perangkat nilai-nilai etis dalam prakteknya.

Di kemudian hari, prinsip politik mulai bergerak menjauh dari tempatnya, yaitu lapangan etika kemasyarakatan. Ini khususnya dimulai dari pemikiran Machiavelli. Hal itu dimungkinkan karena eranya sudah semakin kompleks, sehingga menghasilkan pemikiran-pemikiran yang lebih praktis dalam penyederhanaan. Di sini nilai peradaban manusia menjadi berkurang dalam masyarakat manusia yang ditandai dengan bergesernya etika moral dalam kerangka wacana politik. Dalam The Prince, dikesankan politik etis telah dicampakkan, dan hanya berkaitan dengan kekuasaan dalam arti berkuasa dan mempertahankan kuasa. Dari sini mulai diwacanakan bahwa politik akan menjadi sesuatu yang keras (paksaan), terlepas dari maksud-maksud kebajikannya pada manusia secara umum, atau rakyat dan bangsa, namun semuanya agar kepentingan sang penguasa tercapai. ${ }^{3}$ Memang secara eksplisit dimaksudkan untuk kesejahteraan seluruh penduduk yang dikuasai, namun menekankan taktik berkuasa dan menjalankan kekuasaan. Ini dapat mengindikasikan adanya tekanan besar pada soal kekuasaan, yang terlihat dari prinsip "berkuasalah seperti singa dan seperti serigala". Kemudian hari, prinsip tersebut mungkin saja diperkembangkan lebih lanjut dalam gagasan "etika rajawali" dari Nietzsche yang sangat keras dan memaksa. Kalaupun, "etika" masih ada dalam istilah jargon, namun maknanya sudah berubah dari maksud dan

76 dst. Lih. juga Aristoteles, Nichomaechean Ethics (New York: Oxford University Press, 1998), book 1.

3 Lih. Nicollo Machiavelli, Sang Pangeran, terj. (Jakarta: PT Elex Media Komputindo, 2014), 15-7 dalam Bab XX mengesankan betapa penguasa itu bertindak menguasai dan menaklukkan rakyatnya sendiri dengan kekerasan memaksa rakyatnya untuk setia (189-190) dan mencari ketenaran lebih tinggi bagi dirinya sendiri setelah mengalahkan ketidaksenangan rakyat, yang dipancingnya sendiri (192). 
nilai-nilai luhurnya, yaitu kebajikan masyarakat. Nilai kemanusiaannya telah berangsur dilenyapkan demi kekuasaan total negara. Pandangan politik tersebut masih digunakan oleh banyak hubungan antar negara yang menerapkan prinsip saling bersaing, termasuk dalam negara demokrasi sekarang. ${ }^{4}$

Seorang bernama Thomas Hobbes menyodorkan prinsip Great Leviathan, yaitu suatu hasil ikatan di antara masyarakat yang mempunyai kepentingan-kepentingan berbeda demi mencapai kebutuhan-kebutuhan umum yang sama, dalam apa yang disebut "negara". Itu berdasarkan apa yang dikenal sampai sekarang dengan "kontrak sosial", di mana warga negara harus mengorbankan beberapa hak dan kebebasan individualnya untuk mendapatkan manfaat bersama. Ini adalah suatu prinsip etis juga, hanya etika telah berubah menjadi soal kuasa dan kekuasaan. Jadi negara adalah suatu prinsip persemakmuran (perkumpulan) di antara rakyat untuk mencapai kesejahteraan yang lebih besar. Kemudian perkumpulan tersebut menjadi sangat keras terhadap anggotanya sendiri (rakyat), di mana semuanya harus taat kepada perjanjian persemakmuran, sehingga menjadikan lembaga tersebut menjadi mutlak dan menuntut hak-hak manusia sudah diserahkan secara total. Walau disebut "kontrak sosial" di antara masyarakat, namun eksesnya ternyata menjadi cikal-bakal negara totaliter di kemudian hari, khususnya ketika Nietzsche "mengolah" pemikiran Thomas Hobbes di dalam prinsip-prinsip fasisme Hitler dan Mussolini, serta Kaisar Jepang di era Perang Dunia II.

Walau masih ada dua orang lagi dalam tema kontrak sosial, yaitu John Locke dan J.J. Rousseau, dalam perspektif yang berbeda tetapi maksudnya sama, yaitu mengenai kebaikan bersama dan lebih demokratis untuk orang modern, di dalam hak-hak keadilan masyarakat. Di kemudian hari pemikiran John Locke banyak dipakai dalam demokrasi liberal

\footnotetext{
4 Lih. James W. Skillen, International Politics and the Demand of Global Justice (Burlington: G.R. Welch Co. Ltd., 1981), 16. Beliau mencontohkan dengan istilah-istilah: "big powers, little powers, middle powers, superpowers" antara satu negara dengan lainnya.
} 
Amerika, sedangkan Rousseau dominan diterapkan dalam prinsip demokrasi individual Perancis. Selanjutnya ada seorang yang penting juga bagi demokrasi masa kini, bernama Montesqiu yang sadar akan ekses negatif kekuasaan eksekutif yang dominan dan pentingnya kekuasaan modern, dan dibagi bersisi tiga yang independen bagi suatu negara: eksekutif, legislatif, dan judikatif. Ini dikenal dengan prinsip "trias politica" yang secara prinsip berfungsi sebagai check and balance kekuasaan, agar pemerintahan eksekutif tidak terjatuh ke dalam despotisme. Ini suatu prinsip politik yang baik, asalkan demi kemaslahatan umum dan selalu mendengarkan suara umum. Di sinilah prinsip-prinsip demokrasi modern didasarkan secara kental dengan nuansa etis kemasyarakatan dan moral kemanusiaan. Namun itu baru teoritis saja.

Di sinilah apa yang saya katakan sejak semula, politik telah terlepas dari wadahnya, yaitu etika; bahkan politik tidak mau terkait dengan etika lagi; sehingga muncul sifat immoralnya dalam arti jahat. Politik masa kini bisa menghalalkan segala cara yang jahat: uang, kecurangan, tekanan, kekerasan, kolusi, ancaman, fitnah dll. Semua ini demi kemenangan meraih kuasa dan untuk menduduki kursi atau jabatan politik. Walau dari perspektif Filsafat moral, sebagai induk disiplin ilmunya, kita menyoroti prinsip-prinsip egois dari ilmu ini. Namun sebagai "anak yang telah dewasa", ilmu politik sekarang ini dibedah keluar dari studi ekonomi politik, pertengahan abad $20 \mathrm{M}$ yang lalu. Selanjutnya sebagai ilmu mandiri, ilmu politik lebih mengandalkan ilmu hukum, khususnya hukum tata negara yang dikaitkan dengan ilmu-ilmu sosial. Ironinya, secara praktik sering diikuti dengan pengabaian kesejahteraan rakyat, meskipun dalam pembicaraan level ideal selalu berbicara demi kesejahteraan dan keadilan rakyat. Ini adalah suatu anomali dalam perpolitikan praktis modern. Di satu pihak memprihatinkan keadaan rakyat dan di sisi lain mengabaikan rakyat yang pra-sejahtera. Di sini rakyat hanyalah komoditi politis dan diperalat untuk menuju kekuasaan. Situasi itu dimungkinkan, karena menurut pakar "Hukum tidak memeriksa moral", hukum hanya menegakkan moral 
positif." ${ }^{5}$ Artinya hukum sering mengabaikan hati nurani dan mengandalkan hal positif saja.

Tentunya keprihatinan etis ini menyoroti berdasarkan pemahaman studi filosofis dalam melihat isu kemanusiaan yang lebih baik dan studi historis yang melihat perjalanan kemanusiaan di dalam peradabannya yang modern. Dari sana, ada "pintu masuk dan keluar" yang memadai untuk memikirkan isu-isu keadilan, kebenaran, kesejahteraan, kebersamaan, kesederajatan, dll. Sebagai manusia, dalam fokus aktual dan hal-hal praktis untuk masyarakat. Secara ontologis, politik adalah hakikat yang paling dasar walau spesifik dalam kehidupan. Karena itu secara niscaya dalam level etis, tanpa terkecuali semua orang berpolitik dalam arti bermasyarakat atau berwarga negara. Sederhananya, ilmu politik adalah suatu tata cara pemeliharaan warga negara yang berkeadilan. Jadi wacana etika adalah wadah pembicaraan politik, sekaligus basis dalam praktek politis. Pada kondisi ini, politika bukan sekadar ilmu pemerintahan dan ketatanegaraan pada level taktik (cara saja), tetapi level etik (kemanusiaan) juga. Itu semua terkait dengan aksioma kemasyarakatan, yaitu keadilan dan kesejahteraan adalah hak bagi semua orang. Secara umum prinsip-prinsip dasar adalah prinsip "kontrak sosial" yang lebih mendasar daripada sekadar "kontrak politik" sesaat, seperti yang dilakukan politisi masa kini.

Etika politik lebih menekankan pemikiran secara filosofikal daripada pragmatikal dan berfokus pada kesejahteraan daripada kekuasaan. Jadi kalau bersikukuh bahwa masih ada "etika", maka yang tersisa sudah menyimpang dari maksud nilai-nilai luhur kemanusiaan. Ini suatu anomali dalam lapangan perpolitikan modern yang dikatakan berperadaban maju. Secara umum memang masih ada pembicaraan mengenai kemanusiaan, namun secara praktek mengingkari prinsipnya, artinya etik bermasyarakat telah menjadi taktik berkuasa saja. Dalam pembicaraan perpolitikan masa kini, tersembunyi secara rapi dalam motifnya dua aliran etis, apakah Aristotelian dan Nietszchenian? Aliran kedua cenderung menekankan

\footnotetext{
5 H. L. A. Hart. Hukum, Kebebasan, dan Moralitas, terj. (Yogyakarta: Genta, 2009), viii, ix.
} 
kekuasaan (sekarang kedudukan) yang mendominasi maksud dan pikiran para pemain politik tersebut. Sedangkan aliran pertama lebih menekankan kesejahteraan, keadilan, dan kebersamaan. Ini bukan berarti para politikus tidak membicarakan kemanusiaan dan kemasyarakatan serta kebangsaan, tetapi lebih sebagai jargon politis; dan bukan lagi dalam idealisme kemanusiaan. Celakanya, sekarang ada banyak pengamat, peneliti, akademisi menjadi politikus praktis dan sekutu politikus praktis, serta langsung berubah dalam pembicaraannya menjadi partisan. Ini suatu kelemahan dalam intelektual yang berpendidikan tinggi, bahwa uang dan popularitas dapat membeli idealisme dari para pengamat akademisi, bahkan penelitiakademis.

Di sinilah tantangan bagi manusia berbudaya dan beradab adalah mensintesis kedua motif etis politik dalam tujuan seimbang pada nilai-nilai demokrasi, mengingat para demokrat pun haus kekuasaan dan mengkhianati rakyat demi kekuasaan dan kekayaan. Jadi yang kita perlukan sekarang adalah nilai-nilai moral perpolitikan, di antara para politikus atau antara rakyat dengan elit politik. Semua ini hanya melahirkan talkshow populer belaka di televisi, serta menjadi komedi bagi penonton dan tragedi bagi rakyat banyak. Wacana politik bukan untuk mencari panggung popularitas dan uang semata. Untuk itu, siapa pun dia, apakah seorang politisi, pejabat, dan mahasiswa politik harus mengembalikan nilai-nilai etika dalam tujuan filsafat moral sebagai wadahnya berwacana dan motifnya dalam berbicara tentang kuasa. Dengan demikian cap "keras dan kotor" dalam hal kekuasaan dapat ditanggulangi sedikit demi sedikit; sehingga kecenderungan rakyat untuk chaos atau mahasiswa anarkhi, politisi egois, pejabat yang sewenang-wenang dapat dilampaui. Artinya kita mengembalikan wadah etika bagi politik berarti mengembalikan politik pada maksud dan tujuannya semula, yaitu kebajikan manusia dan kesejahteraan masyarakat secara keseluruhan. Inilah panggilan otentik wacana politik sejak semula. 


\section{Perspektif Etika Teologis Mengenai Perpolitikan}

Perspektif Kristen tentang politik adalah partisipasi aktif, di mana orang percaya harus mempromosikan visi politis yang melampaui kebijakan dan ideologi spesifik, dengan gol tidak harus menjadi agenda legislatif yang terperinci untuk parlemen atau presiden. ${ }^{6}$ Berbicara politik di dalam studi teologis tidak berarti berpolitik, karena tidak sampai pada saran politis keluar dari pemihakan pada partai tertentu, tetapi hanya belajar konsep politis dari perspektif etika Kristen. Sedangkan apa yang dinamakan "teologi politik" diartikan refleksi teologis tentang tatanan dunia yang adil, tidak sama dengan cara untuk memperebutkan kekuasaan secara praktis, di dalam ilmu politik. Etika Kristen-politik dikerjakan dalam kerangka studi teologi. Dalam teologi Kristen, etika politik ini dikerjakan secara refleksi sistematis dengan berpondasi pada kerangka institusi gereja berbeda dengan negara; namun sebagai gereja yang berdimensi sosial juga, maka dapat berkoordinasi dalam dimensi anggota gereja dan warga negara di dalam level masyarakat. Artinya ketika teologi membicarakan tentang politik, itu tidak sama sekali terkait dengan bermain politik, tetapi melihat kontribusi pemikiran Kristen secara nilai-nilai Kerajaan Allah bahkan suara moral kenabian. Hal ini karena politik selalu melibatkan eksistensi manusia dalam relasinya dengan manusia lainnya. Jadi refleksi teologisnya atas keberadaan politisi bukan terkait dengan kekuasaan atau propaganda politik golongan tertentu, dll.

Studi teologi politik adalah wacana menyelidiki tema-tema politis (kemasyarakatan) dalam perspektif ajaran Alkitab yang komprehensif dan memikirkan relevansinya pada situasi sekarang, di mana orang Kristen berada sebagai warga negara dan warga dunia. Teologi politik bukan berarti berpolitik dalam ruang teologi, dengan memakai teks alkitabiah untuk membenarkan diri. Jadi gagasan "teologi politik" di sini adalah refleksi etis tentang hakikat, fungsi, kuasa pemerintahan yang adil berdasarkan

\footnotetext{
6 Doug Bandouw, Beyond Good Intentions: A Biblical View of Politics (Westchester: Crossway Books, 1998), 27.
} 
kebaikan, kebenaran bagi semua warga. Seseorang melihatnya sebagai "tatanan baru", yaitu perjuangan kemunculan suatu teologi gerejawi bagi "tatanan dunia yang adil" yang didasarkan pada prinsip demokrasi.7 Refleksi teologis harus kritis dan bersumber dari ajaran Kitab Suci untuk menunaikan 'mandat peradaban' manusia masa kini demi kelanjutan 'dunia ciptaan'. Kerinduan Kristen menemukan kembali keadilan berdasarkan teologi penyelamatan; "kebangkitan Kristus adalah permulaan sebuah dunia (baru), di mana jenis keadilan baru "dimungkinkan" tentunya melalui perjuangan berat, doa, persuasi dan tindakan politis untuk membuat pemerintah dan kelompok-kelompok revolusioner melihat bahwa ada pendekatan lain ketimbang kekerasan tanpa henti, kekerasan melawan kekerasan." 8 Intinya, studi etika Kristen harus dilanjutkan ke bidang sosialpolitik dengan terus mengingat apa yang dikatakan Carl Henry, "Without strong commitment to justice, our call to Jesus and to evangelical awakening will be feeble." 9 Ini suatu prinsip etika yang memadai dalam upaya menerapkan etika Kristen yang injili. Tentu ini dalam konteks injili di Amerika, namun sejak evangelikalisme adalah gerakan Kristen internasional dan global, maka prinsip ini dapat dipakai di mana-mana, termasuk di Indonesia.

Namun visi politik bukanlah sesuatu yang terpenting dalam "agenda" kekristenan, karena tugas institusionalnya berbeda dan terpisah di dalam misi dunia dengan gereja yang bersifat rohani Kerajaan Allah. Namun sebagai subyek parenial, keprihatinan umum tentang politik tidak bisa dibiarkan, karena institusi plural juga berasal dari Allah yang menggunakan "pedang". Terkait dengan teologi politik diatas, maka etika politik yang disorot dari perspektif Kristen adalah berusaha melihat baik-

\footnotetext{
7 Lihat keseluruhan buku menjelaskan tesis John de Gruchy, Agama Kristen dan Demokrasi, terj. (Jakarta: BPK Gunung Mulia, 2011).

8 N.T. Wright, Hati dan Wajah Kristen: Terwujudnya Kerinduan Manusia dan Dunia, terj. (Jakarta: Waskita Pub, 2012), 263.

9 Carl F. Henry, Christian Mindset in a Secular Society: Promoting Evangelical Renewal \& National Righteousness (Grand Rapids: Baker Books, 1984), 22.
} 
buruk atau salah-benar suatu tindakan atau kebijakan politik, terkait dengan:

a) Pengenalan aspek-aspek politik: hakekat dan tugas plural, kuasa politik, kedaulatan negara di dunia international, asal-usul dan sumber kuasa (legitimasi) pemerintahan, di mana orang Kristen terkena pengaruh sebagai warga negaranya.

b) Sikap gereja kepada negara (sebagai institusi): sikap gereja tidak menciptakan pemerintah (praktis), dalam penafsiran juga tidak dapat dilepaskan dari aspek-aspek kehidupan yang lain dan kepentingan hidup dari komunitas yang lebih luas, serta dilema-dilema yang dihadapi gereja, baik langsung dan tidak langsung harus dihadapi secara suara dan kekuatan moral.

Secara umum pemikiran Kristen dalam etika perluasan ini tidak bersifat politis praktis (kekuasaan). Etika Kristen bagian politik harus tetap pada jalur yang dikenal secara umum dari Carl Henry sebagai "a-political theology" walau dalam usaha injili pun dimungkinkan muncul suatu theology of politics atau "teologi (tentang) politik", yaitu suatu usaha kontekstualisasi teologi yang dalam batas-batas memikirkan "tatanan dunia baru" dalam prinsip-prinsip Kerajaan Allah yang rohani. Itu untuk melihat faktor: kebaikan, keadilan, kemakmuran, dan kedamaian di antara makhluk di dunia yang pluralistik ini, baik secara nasional, regional, dan global. Carl Henry menilai, "political commitments can become readily captive to principle or preferences alien to the church when evangelical movements align themselves uncriticaly with one specific party and promote the election". ${ }^{10}$ Namun, secara bersamaan, kita harus bekerja melalui semua partai yang memperjuangkan kebangsaan dan kebersamaan untuk mempromosikan keadilan dan kesejahteraan bagi rakyat.

Sejak dalam kajian etika, aspek pribadi tidak bisa dilepaskan dari sosial, maka yang dimaksudkan dengan etika sosial di sini, bukanlah etika publik yang berbeda dari etika privat. Secara etika sosial yang injili, ada tiga

10 Lih. Carl Henry, Christian Mindset, 126. 
hal yang patut dipertimbangakan dalam situasi etika kebajikan masa kini, yang saya coba rumuskan kembali sebagai asumsi dasar studinya. 1) Prinsip a-politis, dalam arti tidak sedang berpolitk praktis atau kekuasaan. Tidak memihak atau menjadi corong partai politik tertentu, tetapi berdasarkan nilai-nlai moral Kerajaan Allah dari kenabian gereja. 2) Dari konflik sosial pada dilema etika: tidak menghakimi persoalan politik yang ada, tetapi menilai saja secara metaetik keseluruhan persoalan dalam situasi dilematis. Sejak setiap persoalan sosial etis tidak dapat langsung dijawab ya dan tidak lagi, maka persoalan tersebut berubah kerjanya menjadi dilema etis. 3) Bersifat etika kasuistik, karena persoalan dilematis tersebut menuntut solusi yang komprehensif seimbang dan holistik. Dalam hal ini etika Kristen didasarkan pada realitas transenden, tetapi implikasinya nampak secara imanen dalam ciptaan. ${ }^{11}$ Disini, "Our goal as Christians is not christification of universe, humanization, christinitation,"12 tetapi proses peradaban (civilization). Ini adalah jalan "A prophetic church such also be contrast with servant church whose preeminent concern is to meet human need and to able violate social ill." ${ }^{13}$ Ini yang saya sebutkan sebagai etika kebajikan injili, di dalam rangka berteologi kontekstual, masa kini. Namun ini belum dapat diterima sepenuhnya oleh kaum injili, karena mungkin menyangka, di dalamnya sudah tidak ada prinsip-prinsip kewajiban dan absolut alkitabiahnya lagi dalam kajian etika Kristen.

Dalam kondisi kebangkitan studi etika masa kini, termasuk dalam etika Kristen, kita harus sangat memperhatikan konteks sosial yang lebih lengkap lagi. Secara teologis itu terkait dengan kajian teologis yang lebih komprehensif lagi, khususnya ketika menghadapi konflik moral dan dilematis. Belajar dari Stanley Grenz yang merangkum tiga arah etika

\footnotetext{
11 Donald G Bloesch, Freedom for Obedience: Evangelical Ethics in Contemporary Times (San Fransisco: Pub. Harper \& Row, 1987), 223.

12 Ibid., 239.

13 Ibid., 239.
} 
Kristen masa kini, yang sedang bergerak: 1) dari "doing" kepada "being" dalam penilaian etisnya, 2) dari aktor individual ke relasional dalam fokus etisnya, 3) dari pemenuhan tugas sesorang menuju penemuan kembali sentralitas kasih dalam kehidupan etis, orientasinya bergerak dari pencarian etis menuju penggambaran prinsip eksistensi manusia. ${ }^{14}$ Lalu ada kemungkinan kita dapat menghadapi dilema etis dalam prinsip kebajikan kontekstual, walau secara umum etika injili belum terbiasa dengan situasi kasuistik dibandingkan yang lain. Namun demikian saya meyakini, ini adalah suatu dasar keprihatinan riil dalam teologi injili; artinya tidak harus berteologi liberal dulu baru kita dapat memikirkan hal-hal di atas.Ini adalah keprihatinan injili dalam konteks politik pada masa kini, tidak ada alasan bagi kaum injili untuk mengabaikannya.Pengkajian harus dari perspektif khusus, etik sosial, yang bersifat deskriptif dan bahkan metaetika, yang kajiannya lebih luas dibandingkan etika normatif belaka dan biasa dipakai dalam etika Kristen dasar atau pribadi (disebut juga etika alkitabiah).

Selanjutnya tidak ada salahnya memperjuangkan kembali "hak-hak sipil" kita sebagai warga negara secara konstitusional dan sesuai UU yang berlaku. Dalam situasi ini, kekristenan ada kemungkinannya untuk melakukan pembangkangan sipil, jika hak-hak sipilnya terabaikan. Sikap dan tindakan ketidaktaatan kepada pemerintah ini tidak melanggar perintah Allah (Roma 13:1-5; 2 Pet 3:1-13), karena negara melampaui kekuasaan yang ditetapkan padanya sebagai "pembawa pedang" dengan cara tidak adil. Dalam hal negara yang despotis, kuasa pedangnya sudah "hilang" dengan sendirinya, karena kuasa yang diberikan tersebut dipakai untuk yang tidak seharusnya, seperti yang dimaksudkan Allah semula. Konsekuensinya, meskipun kemungkinan kuasanya masih besar dan dapat mematikan. Secara secara teoritis ada kemungkinan bagi orang Kristen untuk melakukan civil disobedience dalam konteks demokrasi masa kini. Kesalahpahaman dalam doktrin ketaatan sipil Kristen selama ini adalah ketaatan buta yang

14 Stanley Grenz, The Quest of Moral (Downers Grove: InterVarsity Press, 1998), 202-3. Inilah dasar bagi Grenz dalam penyelesaian etik "secara casuistry". 
tidak berdasarkan ajaran firman Tuhan. Dalam konteks sejarahnya, teks teks Alkitab di atas hanya menganjurkan orang Kristen purba untuk tidak ikutikutan yudaisme yang memberontak kepada kekuasaan Roma, karena banyak dari warga gereja mula-mula itu berasal dari Yahudi. ${ }^{15}$

\section{Mandat Transformasi Gerejawi sebagai Jalan Etis Menuju Negarawan}

Kita sudah melihat bahwa secara praktis dari hukum tata negara dan ilmu sosial-politik hanya menjadikan seseorang mempunyai pekerjaan sebagai politikus (politician) dan karier politisi, tetapi tidak menjadi negarawan (stateman). Awalnya negarawan berasal dari para bangsawan dan dari kata aslinya, politicos. Sejak semula berarti baik, yaitu pemimpin atau pengatur masyarakat. Namun sekarang telah merosot menjadi "tukang politik" (politician), yang setara dengan kata "technician" (tukang/insinyur) atau magician (tukang sulap), suatu pekerjaan yang hanya menjual keahlian demi hidup. Semula dapat dikatakan bahwa politikus (politikos) identik dengan negarawan (stateman). Namun sekarang politikus hanyalah pekerjaan pribadi (karier) untuk kekuasaan dan jabatan negara tertentu tanpa jiwa kenegaraan; artinya secara spesifik terlepas dari pengabdian kepada masyarakat dan bangsa; sehingga dikatakan "politician" tidak sama dengan negarawan (stateman). Seharusnya negarawan adalah pengabdian pada warganegara dan demi kemajuan negara. Di sinilah ide pemimpin bangsa menjadi utama di dalam etika kebajikan Kristen.

Nyatanya, politisi penuh dengan intrik, tetapi negarawan bekerja untuk rakyat. Sebenarnya hampir sama seperti bangsawan dalam pengertian ideal istilahnya. Namun para bangsawan kini telah merosot nilainya menjadi negatif sebatas aristokrat sombong saja yang mementingkan diri

15 Bagi yang berkesempatan membaca dapat melihat tulisan saya dalam "Ketidaktaatan Sipil dan pilihat Golput: Sebuah Tinjauan Injili", Indonesia Theological Jurnal, Vol. 3 No. 2 (Desember 2015): 156-184 (E-ISSN2339-0751 Asosiasi Teolog Indonesia [ATI]). 
sendiri, sebagai akibat warisan feodalisme masa lalu. Idealnya, istilah "bangsawan" di sini hampir setara dengan "negarawan," yaitu pemimpin bangsa yang memikirkan kesejahteraan rakyat sebagai warganya. Karena telah jelek konotasinya, maka kita tidak bisa lagi memakai kata "bangsawan", lalu lebih memilih sebutan "negarawan". Memang benar yang menjadi negarawan pada masa lalu terdiri dari para bangsawan. Namun ketidakadilan menjatuhkan penilaian, baik dalam kesewenangan oligarchi dan monopoli dalam monarchi absolut, sehingga para kaum elit politik menguasai kaum "populis" atau rakyat biasa. Era perpolitikan sekarang, politikus bukan berasal dari bangsawan tetapi justru dari populis. Namun sayangnya eks populis ini tidak pernah menjadi bangsawan apalagi negarawan, ketika naik pangkat menjadi elit politik pada jabatan negara dan kekuasaan bangsa. Ini adalah ironi perpolitikan masa kini, para politikus hanya menjadi politisi dalam arti tukang politik yang membodohi rakyat dan memperalat rakyat demi diri sendiri. Sebenarnya, inilah kesempatan para "populis" menjadi politisi untuk membela rakyat. Namun ini tidak pernah sampai pada level negarawan karena diracuni oleh KKN dengan kemunculan kelompok "aristokrasi baru" di dalam konteks demokratisasi, masa kini.

Jadi apakah ada harapan bagi kita orang Kristen? Jawabnya ada, karena berlandaskan etis maka kebenaran bersumber dari Allah.Kalau kita mengakui panggilan moral-etis pada diri politisi yang bersumber dari Allah, maka Allah dapat mencapai kedua-duanya, antara politikus yang negarawan dan negarawan yang politikus. Keduanya sama lapangannya dan jika berdasarkan keadilan dan kesejahteraan masyarakat, maka keduanya dapat digabungkan. Karena pada dasarnya kedua institusi tersebut bersumber dari Allah yang Mahabaik. Biarlah kebenaran Allah tertanam dalam hati seorang politikus dan negarawan tersebut. Karena keduanya adalah panggilan Tuhan bagi seorang anak gereja dan anak bangsa, bukan sekadar mencari dukungan politis di antara warga gereja. Seorang negarawan harus bekerja secara politis agar dapat mencapai secara efektif dan efesien dalam pimpinan negara. Artinya politisi-negarawan atau 
negarawan-politikus sebaiknya menjalankan keseimbangan dalam pemerintahan yang kuat dan adil. Moralitas atau etika Kerajaan Allah secara seimbang menjadi faktor pengikat yang dapat dipakai oleh orang Kriten yang berpolitik praktis. Tentunya nilai-nilai keadilan sosial dan kebaikan Kerajaan Allah sudah tertanam dalam dirinya sebagai "agen perubahan sosial" di dalam masyarakat dan di tengah bangsa dan negaranya.

Mandat sosial gereja dan orang Kristen di dalam masyarakat sebagai "agen perubahan" sosial. Namun banyak kekeliruan mengertinya, misalnya sebagai reformasi saja, yaitu suatu tugas aktif mengubah dunia, seperti dalam aktivis-aktivis sosial Kristen. Tidak ada salahnya aksi sosial Kristen dalam lapangan masyarakat dan politik, tetapi harus proporsional dan tidak kehilangan identitas asli sebagai kekristenan. Sehingga bukan semacam provokasi sosial, layaknya klub-klub sosial di masyarakat. Kalau hal itu yang dilakukan, maka hanya pengejawantahan "Injil sosial". Injil sosial bukan injil yang sebenarnya, hanyalah aksi sosial Kristen. Sebagai agen perubahan sosial, kekristenan di masyarakat bekerja bagaikan 'garam dan terang' (hati nurani sosial masyarakat) dan sebagai 'mercusuar' (referensi sosial). Berdasarkan kebenaran etis, dalam hal ini keberadaannya tetap di sini dan laksana terang menggusur kegelapan secara normal; di mana terang hadir maka gelap hilang, sebagai konsekuensinya. Demikianlah transformasi etis Kristen akan bekerja secara wajar di dalam kegelapan. Jadi tidak perlu mengusir kegelapan, karena transformasi didasarkan pada prinsip nurani dan referensi sosial di atas. Meskipun demikian "mandat gereja harus lebih daripada 'pembaharuan sosial' seperti yang diingatkan Yesus yang lebih menekankan kesejahteraan kekal."16 Jangan sampai gereja bercampur dengan dunia, sehingga kehilangan berita utama, iman Kristen, karena masuknya nilai-nilai duniawi secara bertahap. ${ }^{17}$ Jadi sebenarnya

16 Abraham Kuyper, Iman Kristen dan Problema Sosial, terj. (Surabaya: Momentum, 2004), 38, 39.

17 Ibid., 47. 
dalam kekristenan, transformasi bersifat internal bukan eksternal, nilai-nilai intrinsik daripada ekstrinsik.

Konteks internal gereja adalah umat pengikut Kristus. Gereja-gereja adalah wujud dari pengikut Yesus secara kelihatan dan organisasi. Dalam konteks politik etisnya, orang Kristen dalam dunia dan masyarakat, kita tetap mengingat nasihat lama ini: "The church must beware of relying too heavily upon politic and economic means to deal with social evil. Our calling and our mission go broader and deeper than the political process ever could..." Selanjutnya, the church needs to be active in both fronts, in the political arena and in the larger society, striving for social righteousness in all aspects of its mission. We are to be leavening agents that permeate all of life with the presence and promote of God's reign' 18 yang menurut Os Guinness, panggilan Kristen kita adalah, bukanlah kristendom lagi, dalam arti keagamaan politis geografis dalam agama Kristen, yang penuh dengan ekslusivisme dan mengucilkan (yang) selalu muncul dari berhala palsu kemurnian... farisiisme adalah hasil dari suatu hasrat akan kemurnian teologis yang menyimpang sama seperti pembersihan etnis adalah hasil dari suatu kemurnian rasial yang menyimpang."19

Bagi warga gereja, secara keseluruhan ada anomali dalam dunia politik masa kini.Suatu keharusan positif sekaligus negatif; kebaikan sekaligus keburukan.Sikap etis penting untuk mengembalikan politik masa kini menjadi suatu yang baik seperti semula, yaitu kesejahteraan dan keadilan bersama.Di sinilah gereja-gereja harus mereposisikan etika, karena secara umum moral-etis berdasarkan Allah sendiri dalam kebenarankebenaran-Nya, sedangkan politik hanya berdasarkan sosialitas-legal manusia belaka. Tugas dan tanggung jawab gereja dalam dunia politik cukup penting, khususnya sebagai "agen perubahan sosial", "hati nurani" masyarakat dan sampai pada tingkat aktivisme politik, khususnya bagi

\footnotetext{
18 Bruland and Mott, A Passion for Jesus Passion for Justice (Valley Forge: Judson Press, 1983), 92.

19 Os Guinness, Panggilan Allah: Menemukan dan Menggenapi Tujuan Utama dalam Hidup Anda, terj. (Bandung: Pionir Jaya, 2011), 154.
} 
warga gereja yang berprofesi politikus. Dalam Pembinaan Warga Gereja (PWG), seharusnya menekankan kebajikan dan keprihatinan sosial Kristen daripada kedudukan politisnya. Kedudukan dan wewenang politis hanyalah alat yang baik untuk mensejahterakan rakyat. Artinya kedudukan politis dicapai bukan hanya untuk memperkaya diri sendiri, tetapi untuk mengabdi kepada rakyat secara keseluruhan kelak, entah konstituennya atau tidak. Artinya menjadi seorang negarawan adalah sebagai pemimpin bangsa yang harus mengayomi seluruh rakyat secara adil dan mengajak rakyat untuk membangun bersama-sama. Di sinilah para politikus harus belajar dan tidak hanya memperalat rakyat untuk dirinya sendiri.

Dalam prinsip Garam dan terang dunia, gereja adalah hati nurani sosial dan referensi sosial di dunia ini, sekaligus prinsip dasar sebagai agenagen perubahan sosial dalam masyarakat. Selanjutnya sebagai dasar aksi sosial, gereja tidaklah berpolitik praktis, namun masih tetap dapat berkonsultasi dengan pemerintah pada level intelektual dalam kebijakan publik, bukan sharing kekuasaan. Para gerejawan politis selama ini harus sadar bahwa ini dalam batas-batas politik etis. Sebenarnya, dalam prinsip mayoritas moral, memang gereja kecil secara populasi tetapi pengaruhnya besar karena berdasarkan kebenaran moral, untuk kebenaran universal, dan bersumber dari kebenaran Ilahi. Kebenaran dalam hal keadilan sosial nyata hadir dalam rakyat secara umum, walau jumlahnya kecil. Namun "suara nurani" itu ada secara universal dalam diri manusia dan "suara mayoritas" hanya ada dalam voting. Faktanya suara mayoritas dapat dibeli dan diancam. Kita mengenal dalam prinsip vox populi vox dei, suara rakyat adalah suara Allah, dalam pengertian sosial, bukan teologis, di mana Allah berpihak kepada orang kecil dan orang miskin; jeritan orang miskin adalah suara Allah sendiri. Di sinilah panggilan kenabian gereja itu berjangkar. Dalam hal ini gereja harus bersuara kenabian untuk mengingatkan pemerintah akan ketidakadilan dan ketidakberhasilannya menanggulangi kemiskinan. Sebagai hati nurani rakyat, politisi-negarawan adalah penyambung lidah rakyat atas nama Allah kepada pemerintah. Faktanya 
secara rohani, Allah sering berpihak pada orang miskin.

Ditengah-tengah permainan politik sekarang, di mana "bahasa politik" harus memikul beban kesalehan palsu yang justru menjadi kehausan politikus saat ini. ${ }^{20}$ Disini Gereja menghimbau para elit politikKristen harus menjadi negarawan dulu, setidak-tidaknya menjadi politikus (politicos) yang semula, yaitu para bangsawan, dengan segala pemikiran kemanusiaan secara filosofis dan historis.Politikus harus menyadari kelemahan pikirannya yang selama ini hanya sebatas "tukang" politik, yang sibuk dengan prosedur hukum dan rekayasa-rekayasa sosial demi demokratisasi. Hampir pasti, jika sebatas "pemain politik" saja, maka hanya akan menjadikan para politikus sebagai "tikus-tikus politik". Walau mungkin berasal dari rakyat (populis), tetapi tidak mau mengayomi rakyat tempat dia berasal, khususnya pada masalah kemiskinan. Ini suatu ironi demokrasi era reformasi saat ini.

Gereja harus membimbing dengan suara moral dan kenabiannya untuk menjadi negarawan daripada politikus saja. Secara khusus, prinsip politikus harus menjadi negarawan ada dalam tugas sosial gereja. Jadi gereja tidak bisa berbangga pada anggotanya yang tinggal diam dalam kedudukan jabatan politik atau sebatas jabatan kenegaraan saja, namun tidak menjadi negarawan. Sikap kenegarawanan sangat penting sebagai abdi masyarakat dan pejabat negara kelak. Melihat politikus masa kini hanya menekankan aspek hukum positif, tetapi melupakan jiwa dari hukum itu sendiri, yaitu keadilan. Negarawan harus bijaksana dan lebih luas horizon pandangannya berdasarkan studi kemanusiaan. Tujuan yang mendasarkan aspek legal formal yang sempit hanya menjadikan seseorang sebagai politikus Kristen belaka. Tetapi jika menekankan aspek kesejahteraan sosial manusia, maka menjadikan seseorang negarawan yang Kristen. Kita dapat belajar dari Abraham Kuyper dan William Wilberforce. Saya kira masih ada harapan bagi masyarakat bila gereja terus menyuarakan keadilan dan ikut aktif

20 Lih. David Wells, Hilangnya Kebajikan Kita, terj. (Surabaya: Momentum, 2005), 11. 
menolong orang miskin.

\section{Panggilan "Politisi-Negarawan" untuk Kesejahteraan Sosial, Kemiskinan}

Khusus dalam masalah kemiskinan, usaha reformasi itu dipikirkan di bawah ini. Artinya seorang negarawan yang berasal dari politisi harus memperhatikan rakyat, karena dasarnya ia berasal dari rakyat, bukan bangsawan. Jadi ia mempunyai hati nurani rakyat juga sebagai teman sependeritaannya dulu. Pemikiran yang injili mendorong gagasan baik ini, karena merupakan warga gereja dan warga negara yang menerima panggilan Tuhan sebagai politisi-negarawan. Negarawan adalah seorang pemimpin rakyat yang dapat memberikan solusi-solusi dalam permasalahan rakyatnya dan pemberi pengharapan masa depan, serta mensejahterakan masyarakat dengan adil. Di sinilah pentingnya politikus harus mengubah paradigma politiknya menjadi negarawan. Negarawanlah yang dibutuhkan, bukan politisi bagi Indonesia masa kini.

Memang sebagai injili, kita harus mengakui bahwa kita lebih prihatin tentang dosa individual daripada prihatin pada dosa struktural atau kejahatan sosial, yaitu dosa ketidakadilan. ${ }^{21}$ Absolut menurut saya adalah tidak ada harapan dan tidak ada kesempatan untuk meningkat lagi, suatu kemiskinan total dari segi ekonomi (SDM), politik (masalah $\mathrm{KKN}$ ), dan budaya (utang luar negeri), ini akan menjadikan bangsa Indonesia menjadi bangsa budak dan kuli di negeri orang lain, walaupun mendatangkan devisa bagi negara dan menyumbangkan peningkatan persentasi ekonomi. Negara memperbudak rakyatnya, yang seharusnya disejahterakan berdasarkan tugas konstitusionalnya. Dalam hal ini pemerintah yang berkuasa harus bertanggung jawab sebagai penerima mandat rakyat.

Sudah ditegaskan, bahwa kekristenan, injili khususnya, sangat peduli

21 Ronald J. Sider dalam The Ministry of Development in Evangelical Perspective (Pasadena, CA.: William Carey Library, 1979), 37, 38. 
dengan masalah sosial. Abraham Kuyper pernah menantang orang Kristen, yang mencoba mengabaikan masalah kemiskinan ini, yang biasanya didasarkan pada teks alkitabiah "orang miskin akan selalu ada padamu". Sebagai seorang Negarawan, Kuyper melihat ini sebagai ketidakmengertian ayat tersebut dan dijadikan sebagai alasan untuk tidak perlu menanggulangi problematika sosial, khususnya kemiskinan. Menurutnya, banyak orang Kristen berada dalam jalur kemasabodohan ini; padahal Alkitab khususnya dalam berita nabi-nabi memerangi ketidakadilan sosial, khususnya masalah kemiskinan. ${ }^{22}$ Masa kini, Ron Syder melihat bagaimana kemunafikan dan ketidakpedulian orang Kristen "lahir baru" pada lingkungannya, diskriminasi, rasialis, tidak peduli orang miskin, kekerasan rumah tangga, materialism, korupsi dll. ${ }^{23}$ Secara terbatas saya melihat ini sebagai "hilangnya kebajikan Kristen" di mana karakter-karakter baik orang Kristen tidak ada dampak lagi dalam kehidupan sosial. Untuk itu saya memanggil kembali prinsip etika sosial John Stott, yang pernah saya pergunakan dalam tulisan terdahulu, yaitu "doktrin-doktrin Kristen yang lebih genap." Prinsip ini terkait dengan relevansi dan implikasi ajaran teologis pada situasi praktis manusia secara sosial. Ini adalah nasihat etis untuk kepemimpinan Kristen masa kini. Singkatnya, memprihatinkan permasalahan sosial seharusnya tidaklah mengherankan bagi kaum injili, meski ada beberapa yang mengabaikannya dan lainnya hanya provokasi masyarakat. Keprihatinan sosial seharusnya menjadi tantangan intelektual bagi kaum injili.

Kaum injili mengakui bahwa kesejahteraan sosial adalah isu yang paling penting pada era ini. Khusus dalam era demokrasi dan perjuangan HAM, lalu mengerucut pada permasalahan kemiskinan yang menjadi sorotan tajam manusia se-dunia. Kemiskinan adalah masalah terparah negara modern, sekaligus menjadi isu yang paling ampuh untuk para politikus yang berkampanye mencari dukungan massa, walau janji-janji saja.

\footnotetext{
22 Abraham Kuyper, Iman Kristen dan Problema Sosial, terj. (Surabaya: Momentum, 2004), viiiix.

23 Hal ini didalami oleh Ronald J Sider, Skandal Hati Nurani Kaum Injili, terj. (Surabaya: Perkantas Jatim: 2007), 27-44.
} 
Indonesia misalnya, sejak semula sudah mengikatkan diri untuk mewujudkan keadilan sosial bagi seluruh rakyat, dan sekarang sedang giat memberantas kemiskinan. Tetapi di balik itu, kebangsaan ini menghadapi situasi ancaman disintegrasi, karena masalah ketidakadilan sosial yang tidak kunjung tertanggulangi, khususnya dalam lapangan ekonomi, tepatnya kemiskinan dalam masyarakat. Dalam UUD '45, Negara bertugas untuk memelihara rakyatnya secara kesejahteraan sosial bahkan diejawantahkan dalam batang tubuh UUD pada pasal 34 bahwa jelas tertulis "orang telantar dan fakir miskin dipelihara" negara. Namun kita lihat semakin banyak anak jalanan, pengangguran, kriminal, pemecatan, dll. Apakah ini yang sesungguhnya dimaksudkan "pemeliharaan negara, yaitu "memelihara kemiskinan", sehingga tidak ada keinginan ekonomi-politis untuk memberantas kemiskinan, lalu orang miskin dibiarkan saja sebagai ladang pekerjaan pemerintah dari periode ke periode. Namun dalam falsafah negara dan bangsa ini jelas mencantumkan sila kelima, tentang "Keadilan sosial bagi seluruh rakyat Indonesia" dengan lambang "padi dan kapas" untuk menunjukkan betapa pentingnya sandang, pangan (dan papan) bagi rakyat ini.

Asalinya tujuan masyarakat politis dalam suatu negara apapun adalah kesejahteraan rakyat. Hal ini sedikit banyak tercantum dalam konstitusinya. Kesejahteraan rakyat dan kedamaian bangsa tidak bisa dilepaskan dari keadilan sosial dan ekonomis. Jadi diperlukan keadilan distributif selain keadilan retributif. Keduanya harus seimbang dalam masyarakat sipil, tetapi harus sadar akan proporsionalitasnya dalam penerapannya. Rakyat perlu hidup layak sebagai warga negara, kalau tidak akan merasa tertindas oleh hukum dan tidak mau taat hukum sama sekali. Sedangkan para "elite' politik menikmati fasilitas negara dan keberhasilann ekonomi, yang notabene rakyat yang menanggungnya. Sementara para pejabat negara dan elit politik di parlemen hidup bermewah-mewah di atas penderitaan rakyat yang adalah konstituennya. Di sini pejabat tanpa malumalu hidup mewah dari sokongan rakyatnya. Ini memang ironi di dalam 
demokrasi masa kini yang kebablasan.

Hampir pasti saya menilai apa yang dituliskan oleh Denis Breton dan Christopher Largent tentang jiwa teori-teori ekonomi masa kini adalah "ketamakan dan uang", di mana satu persen orang kaya menguasai kesejahteraan orang banyak yang intinya menyebabkan poverty dan homelessness secara ekonomi. Bahkan kedua penulis itu merasa para pencipta teori-teori ekonomis ini mengabaikan isu-isu yang dilontarkan dari perspektif keagamaan dan filosofis tentang "krisis makan malam", di mana ekonomi dengan kekuatan besar menggunakan apa yang dikatakan "blind laws of economics" tanpa gagasan-gagasan tentang kesejahteraan umum yang dipertanyakan oleh agama dan filsafat, sebagai reflektornya. Sejalan dengan itu ia melandaskan dynamics of spiritual growth, khususnya dari perspektif agama Kristen menuju pasar yang didasarkan pada 4 langkah. ${ }^{24}$ Di Indonesia bukan hanya pengusaha yang tamak, tetapi para politisi dan birokrat menguras uang rakyat demi kesejahteraan diri sendiri. Mereka hidup keenakan dengan dibayar oleh orang miskin.

Dalam usaha pengentasan kemiskinan, peran pemerintah sangat penting dalam hal pendidikan rakyatnya, karena tanpa sumber daya manusianya yang baik, maka tidak bisa mengentaskan dirinya secara ekonomi. Karena tidak ada kesempatan untuk meningkat. Ini pun suatu dilema karena pendidikan memerlukan biaya yang tidak sedikit dan anggaran pemerintah kurang dalam hal ini. Namun hal ini tidak bisa diatasi selain kebijakan pemerintah, dalam hal ini adalah keinginan politisnya (political will). Ini adalah ketidakadilan sosial menuju ketidaksejahteraan sosial, khususnya kemiskinan ekonomi, lalu ketidakterdidikan masyarakat dan terus berputar seperti lingkaran setan. Alam demokrasi seharusnya mengangkat yang lemah dan kecil. Pemerintah harus menekan KKN dan mendorong kehidupan masyarakat yang lebih baik dalam gagasan masyarakat sipil. Saya kira ada masalah moral juga, khususnya mentalitas

24 Denis Breton \& Christopher Largent, The Soul of Economies (Willmington: Idea House Pub. Co., 1999), 1 dst. 
politis yang tidak sehat dan memelihara situasi ini untuk kepentingan golongan dan perorangan. Menurut Kuyper, "Permasalahan sosial tidak pernah menjadi permasalahan selama hal tersebut bukan merupakan sebuah kritik "arsitektonik" (menyeluruh) terhadap bangunan sosial, di mana kita menghendaki terbentuknya tatanan dunia yang baru. ${ }^{25}$

Kalau hal itu hanya berdasarkan hitung-hitungan kapitalisme liberal semata, memang di lapangan tidak terasakan. Di sini saya tidak bermaksud mempertentangkan kembali sistem ekonomi kapitalisme liberal dan sosialisme marxis yang sudah lama usang, sejak runtuhnya ideologi komunisme. Dalam tulisan Fukuyama, The End of The Man, dikesankan bahwa demokrasi dengan kapitalisme liberalnya adalah harapan manusia modern, satu-satunya arah tujuan masyarakat ke masa depan. Inikah utopia itu? Mengingat sistem liberalisme ekonomi sekarang sedang jatuh, dan konon perannya digantikan ekonomi syariah, karena ekonomi marxisme komunis juga telah gagal diharapkan, sebelumnya. Apakah ekonomi syariat Islam adalah alternatif sejati yang kita cari selama ini? Saya kira tidak! Tidak mungkin ada prinsip sempit dapat mejangkau dunia yang berbagai prinsip, kecuali hanya ingin menguasai dunia berdasarkan prinsip-prinsip radikalnya. Kalau kita lihat bahasa John Stott tentang kemiskinan, khususnya dalam konteks negara-negara maju dan negara berkembang/miskin, yang digambarkan "Utara-Selatan”, jelaslah kita dapat melihat sistem kapitalisme hanya membawa pemiskinan bagi negara miskin. Semua bemuara pada masalah ketidakadilan sosial secara internasional. Para kapitalis menguras sumber daya negara-negara Selatan untuk industri mereka, serta meninggalkan sampah dan kemiskinan, karena pembagian yang tidak adil. Bangsa Indonesia merasakannya. Lengkaplah proses pemiskinan tersebut dialami oleh orang kelas bawah negeri ini, dari pemerintahnya sendiri, saudaranya, dan negara-negara maju yang

25 Abraham Kuyper, Agama Kristen dan Problema Sosial, terj. (Surabaya: Momentum, 2004), 59. 
kapitalistik.

Dalam situasi ini, memang benar prinsip kapitalisme membuat keraguan kita akan kondisi ekonomi yang semakin sulit. Karena kapitalisme selama ini dilihat sebagai hal yang jelek dan tidak adil dari perspektif sosialisme, 1) System of voluntary human relationship in which people exchange on the basis of the peaceful means of exchange. 2) Capitalism is not economic anarchy. 3) Capitalism also presuppose a system of morality. 4) Capitalism does not encourage people to do anything they want. 5) Capitalism should be regarded as a system ...within a frame work of law which protect peoples right against force, fraud, and violations of contracts ...the corruption deserve condemnation, but the system was not capitalism. ${ }^{26}$ Namun demikian tetap ada beberapa keberatan moral terhadap kapitalisme seperti eksploitation, free exchange, zero-zoom game, selfishness, greed, competitiveness. ${ }^{27}$

Menurut Berliner, ekonomika masyarakat bukanlah masalah pengalaman negara-negara atau tentang ekonomika mereka, tetapi entang "economic system", yaitu "Reffers to the set of institution, rules and practices" yang disebutnya "institutional arrangements", di mana suatu economy bekerja. Jadi "economy is a social network of person and organizing thet participate in production and distribution of good and services." Jadi keadilan bagi orang banyak terkait dengan criteria of an economy's goodness. Keadilan di sinisecara khusus terkait dengan barangbarang ekonomis dalam dua hal fairness, pengertiannya terkait dalam pengaturan menjadi adil (fairness dan kesamaan) "equity: yang terkait dengan distributive justice...of income dalam masyarakat termasuk: standard fairness, equality, poverty."28Di sini kaum injili berpendapat, "Our goal as christian is not christification of universe, humanitation, christianitation, but

\footnotetext{
26 Ronald H. Nash, Poverty and Wealth: The Christian Debate over Capitalism (Westchester: Crossway Books, 1988), 66.

27 Ibid., 71-3.

28 Ibid., 23, 24.
} 
civilitation. $^{29}$

Khususnya terkait dengan ketimpangan ekonomis antara negaranegara maju dan berkembang, yang dirasakan bahwa negara miskin sedang memperjuangkan hak kemerdekaan ekonomi, sesudah mendapatkan hak kemerdekaan politiknya. ${ }^{30}$ Ada baiknya diperhatikan keprihatinan komisi (Brendt) yang dibentuk untuk mengatasi problem kesenjangan tersebut, dalam laporannya, "perkembangan adalah lebih daripada lintasan dari miskin ke kaya; dari ekonomi tradisional ke ekonomi canggih perkotaan; wawasannya bukan sekadar mencakup kenaikan tingkat ekonomi, melainkan kenaikan harkat dan martabat manusia, keterjaminan dan keadilan serta kesamaan hak." ${ }^{31} \mathrm{Hal}$ ini tetap harus mewaspadai munculnya plutokrasi di dalam masyarakat. Karena disinyalir oleh beberapa orang bahwa demokrasi masa kini meskipun tidak ada konflik dengan HAM, tetapi karena pengaruh uang yang besar dimainkan dan dituju pemerintah, "sehingga mengancam akan menggantikan demokrasi menjadi plutokrasi, pemerintah yang mementingkan kepentingan keuangan." 32

Sebenarnya studi ekonomi didasarkan ekonomi politis pada mulanya dalam kajian filasafat moral yang dibangun abad 18 sebagai suatu studi ekonomi negara, lalu menjadi ekonomi politik dan sekarang disebut "ekonomika"saja. Dari kajiannya jelas bahwa ekonomi sangat erat hubungannya dengan politik. Tanpa politik, ekonomi tidak besar dan tanpa ekonomi politik akan mandeg. Ekonomi secara khusus mampu memobilisasi masyarakat dalam kehidupan lebih dari politik dan agama.Namun ekonomi tidak dapat berdiri sendiri juga, karena jalannya harus diatur dan dikembangkan oleh politik.Jadi secara khusus, ekonomi politik mempelajari produksi, pembelian, penjualan, dalam relasinya

\footnotetext{
29 Ibid., 239.

30 John Stott, Isu-Isu Global: Menantang Kepemimpinan Kristen (Jakarta: OMF/YKBKB, 1992.), 166.

31 Ibid., 169.

32 Stassen \& Gusheen, Etika Kerajaan, terj. (Surabaya: Momentum, 2008), 207.
} 
dengan hukum kebiasaan dan pemerintah.Singkatnya politik yang menyatukan ekonomi, bukan sebaliknya, karena harus ada kekuatan pemerintah untuk mengaturnya.Sedangkan kajian sosio-ekonomi melihat relasi.Hal ini semua untuk menciptakan kesejahteraan sosial bagi rakyat banyak dan mengurangi kemiskinan.

\section{Penutup}

Saya kira masih ada harapan bagi masyarakat, apabila gereja terus menyuarakan keadilan dan ikut aktif menolong orang miskin. Memang pemberantasan kemiskinan adalah tugas utama dari pemerintah atau negara, namun gereja dapat berpartisipasi secara etis dan aktif menolong pemerintah mengatasi kemiskinan. Untuk itulah, salah satu alasan kita berada di dunia ini.Dengan demikian, sebagai anak gereja kita harus menyadari, bahwa kajian kita teologis, bukan politis. Karena gereja tidak berpolitik, tetapi menyalurkan refleksi-refleksinya tentang kemasyarakatan ini dalam pengaruh-pengaruh etis Kerajaan Allah dan suara kenabian gereja. Dalam hal ini, studi etika Kristen bagian sosial politik adalah pengaplikasian studi etika secara kontekstual, di bawah mata program studi teologi sistematika. Singkatnya wacana politis dalam studi teologis tidak dapat dipolitisir oleh siapa pun dan dibatasi dalam kajian etika Kristen, sebagai pelajaran applied doctrine. Inilah tujuan ideal studi etika sosial Kristen bagian politik yang kita pelajari selama ini.

Seorang negarawan mendahulukan bangsa dan rakyatnya, bukan kepentingan sendiri dan kelompoknya. Bukan sekadar merebut kursi tetapi melayani rakyat. Di sini seorang negarawan berbeda dengan politisi, semua demi bangsa dan negara. Politisi sebagai tukang politik hanyalah soal kursi dan kekuasaan demi kelompoknya yang kecil. Khususnya bangsa ini, politik etis dibutuhkan melampaui politik praktis, yang pertama bersifat fundamental, yang kedua pragmatikal bagi kemanusiaan. Secara pragmatik, Politisi tidak malu berbuat jahat demi kekuasaan dan hanya mengandalkan uang dan tipuan dalam pembicaraan tanpa peduli kebenaran dan keadilan moral. Politisi sekarang adalah "tukang politik" bersikap jahat dalam arena 
politik yang bersifat jahat. Tetapi negarawan tidak hanya kekuasaan dan keuntungan semata-mata, maka harus melampaui sikap politisi yang hanya main politik tanpa mengurus kesejahteraan bangsa dan rakyat.

Jadi prinsip politisi-negarawan atau negarawan-politisi masih ada kemungkinannya, khususnya dari penilaian etika Kristen, seperti sudah dijelaskan pada bagian sebelumnya. Politisi pun dapat memimpin bangsa ini, bukan hanya para bangsawan, karena yang terpenting adalah sikap kenegarawanannya. Politisi-negarawan Kristen mendasarkan diri pada nilainilai kebenaran Kerajaan Allah untuk mentransformasikan masyarakat, sekaligus dapat mereformasinya juga. Terkait dengan era reformasi Indonesia ini, saya melihat demokrasi baru dalam level sistem perpolitikan, belum menjadi pandangan hidup kita. Makanya kita banyak melihat politisi cekcok soal yang tidak penting (sekunder) daripada permasalahan inti kemasyarakatan, misalnya keadilan dan kesejahteraan rakyat. 